\title{
For Your Bookshelf
}

\section{Essentials of Corporate Communication: Implementing Practices for Effective Reputation Management}

\author{
Cees B.M. van Riel and Charles J. Fombrun \\ Routledge, London and New York; ISBN 978-0415328265; 408pp; paperback, \\ US\$44.95
}

Corporate Reputation Review (2007) 10, 73-74. doi:10.1057/palgrave.crr.1550039

In 1992, Van Riel's book 'Identiteit en imago' ('Identity and image') was one of the first, if not the first, monographs to systematically cover the field of corporate communication from an academic perspective. Earlier books, like Riley and Levy (1963), Olins (1978), and Garbett (1988), were primarily practice-oriented, while more academically oriented books like Frank and Brownell (1989) and Jablin et al. (1987) focused on specific areas within corporate communication. Van Riel's book was very well received on the Dutch market, and published in English by Prentice Hall in 1995. Now, Van Riel and Fombrun, who cofounded both the Reputation Institute and the $C R R$, have collaborated to substantially revise and update the book. They have added many new practical examples and discussions of recent academic studies, as well as treatments of additional topics.

The new edition basically has the same structure as the 1995 book. Like its predecessor, the book implicitly consists of two parts, the first part dealing with the principles of corporate communication (Chapters 1-5), and the second with its practical implementation (Chapters 6-11). The book is guided by two propositions:
(1) the goal of all corporate communication efforts is to enhance corporate reputation, and (2) all efforts should be coordinated and consistent in order to be effective.

Compared to the previous edition, the sections on the measurement of reputation and identity were separated from their conceptual counterparts and turned into separate chapters, while four new chapters were added ('Communicating with the corporate brand', 'Developing a reputation platform', 'Communicating with key stakeholders', and 'Applied reputation research'). I think this revised structure has improved the flow of the book, which is now structured more like a story, following the different steps that companies can take in developing corporate communication. On the other hand, the increase in the number of chapters does make it a bit more difficult to navigate through the book by using the table of contents. This is also complicated by some of the chapter titles: for example, for many readers it might be difficult at first sight to tell the difference between topics like 'Communicating with the corporate brand', 'Expressing the company' and 'Communicating with key stakeholders'.

The four new chapters do offer valuable and detailed insights relevant for both
Corporate Reputation Review Vol. 10, No. 1, pp. 73-74 (C) 2007 Palgrave Macmillan Ltd, 1363-3589 $\$ 30.00$ 
academics and practitioners. The chapter on 'Communicating with the corporate brand', in addition to giving an overview of the internal decision-making processes surrounding corporate brands already present in the previous edition, also provides a useful discussion of the literature on the value of the corporate brand for consumers, which was still in its infancy at the time of the earlier edition (really only starting off with Brown and Dacin's (1997) seminal publication). The chapter on the 'reputation platform' offers an interesting overview of the emerging topic of storytelling and its relevance for organizations. 'Communicating with key stakeholders' (about the different specialized communication functions) provides insights into (among others) the relatively new field of experience marketing, while the 'Applied reputation research' chapter is a useful overview of different standardized reputation measures available.

One of the strong points of both the old and the new editions of the book is that it pays ample attention to the historical origins of the constructs discussed. The ideas of "classical' authors like Birkigt and Stadler, Larçon and Reitter, Bernstein, and Olins regarding the central concepts of identity and reputation are all given detailed attention. This attention is all the more valuable since some of these ideas were published in languages other than English and therefore might not be accessible to many readers. This historical perspective is important and refreshing in a field in which, like in many other areas in management and communication, it can be tempting for researchers to follow the latest business fads and fashions, rather than engaging in a discussion that has evolved over several decades.

In addition to this historical context, the authors provide a comprehensive overview of more recent academic literature. In doing so, they show that they are familiar with the developments in such diverse fields as corporate finance, organizational behavior, brand management, and human resource management. Besides the academic literature, there is a comprehensive overview of practical tools and models that can be used by communication managers as a useful guideline for developing a communication campaign. The book guides the manager through the whole process, from uncovering the basic concepts that define who the company is, through designing and implementing a core message, up to monitoring the effectiveness of the campaign.

Overall, the book provides a very good overview of a field that has developed tremendously over the past decade. Its attention both to the historical context of concepts like corporate reputation and identity, as well as to the many recent academic and practical studies that have been published makes it a valuable read for both academics and practitioners working in corporate communication.

\section{Guido Berens RSM-Erasmus University}

\section{References}

Brown, T.J. and Dacin, P.A. (1997) 'The company and the product: Corporate associations and consumer product responses', Journal of Marketing, 61(January), 68-84.

Frank, A. and Brownell, J. (1989) Organizational Communication and Behavior: Communicating to Improve Performance $(2+2=5)$, Holt, Rinehart and Winston, New York.

Garbett, T.F. (1988) How to Build a Corporation's Identity and Project its Image, Lexington Books, Lexington, MA.

Jablin, F.M., Putnam, L.L., Roberts, K.H. and Porter, L.W. (eds.) (1987) Handbook of Organizational Communication: An Interdisciplinary Perspective, Sage, Newbury Park, CA.

Olins, W. (1978) The Corporate Personality: An Inquiry into the Nature of Corporate Identity, Design Council, London.

Riley, J.W. and Levy, M.F. (eds.) (1963) The Corporation and its Publics: Essays on the Corporate Image, John Wiley, New York.

Van Riel, C.B.M. (1992) Identiteit en imago, Academic Service, Schoonhoven.

Van Riel, C.B.M. (1995) Principles of Corporate Communication, Prentice Hall, London. 